\title{
Syväluotaus Taidehallin näyttelytoimintaan Bertel Hintzen toimikaudella
}

\section{Tuuli Lähdesmäki}

\section{Maija Koskinen, Taiteellisesti elvyttävää ja poliit-} tisesti ajankohtaista - Helsingin Taidehallin näyttelyt 1928-1968. Taidehistorian väitöskirja, Helsingin yliopisto, 2019, 340 s. https://helda.helsinki.fil handle/10138/282224

Taideinstituutioiden toiminnan tarkastelu on keskeinen osa taidehistorian tutkimusta. Tätä toimintaa on valotettu viime vuosikymmenten aikana useissa kotimaisissa taidehistorian väitöstutkimuksissa. Näistä varhaisimmassa, vuonna 1999 ilmestyneessä Marja-Liisa Rönkön väitöskirjassa, tutkimuksen keskiössä on koko suomalaisen taidemuseoinstituution muotoutuminen suhteessa taidemuseotoiminnan kansainvälisiin kehityskulkuihin. ${ }^{1}$ Vuonna 2008 ilmestyneet Susanna
Petterssonin ${ }^{2}$ ja Hanne Selkokarin ${ }^{3}$ väitöskirjat tarkastelivat kotimaisten taideinstituutioiden ja näytteIytoiminnan kehittymistä 1800- ja 1900-luvuilla aikakauden merkittävien kulttuurielämän vaikuttajien, taiteen tuntijoiden ja keräilijöiden Fredrik Cygnaeuksen, Carl Gustaf Estlanderin ja Eliel Aspelin-Haapkylän kautta. Taideinstituutioiden toimintaa on analysoitu kotimaisissa taidehistorian väitöksissä toki myös ajallisesti nuorempien nykytaiteen esimerkkien ja ilmiöiden näkökulmasta. ${ }^{4}$

Maija Koskisen väitöstutkimus Helsingin Taidehallista suomalaisen taidekentän keskeisenä toimijana ja suunnannäyttäjänä jatkaa kotimaisten taidehistorian väitöskirjojen instituutio-tutkimusta. Koskisen tutkimus rajautuu Taidehallin ensimmäisen intendentin Bertel Hintzen toimikauteen ja käsittää siten kaikkiaan viisi vuosikymmentä 1920-luvun lopulta 1960-luvulle. Tuohon ajanjaksoon sisältyy monia sekä suomalaisen yhteiskunnan että taide-elämän

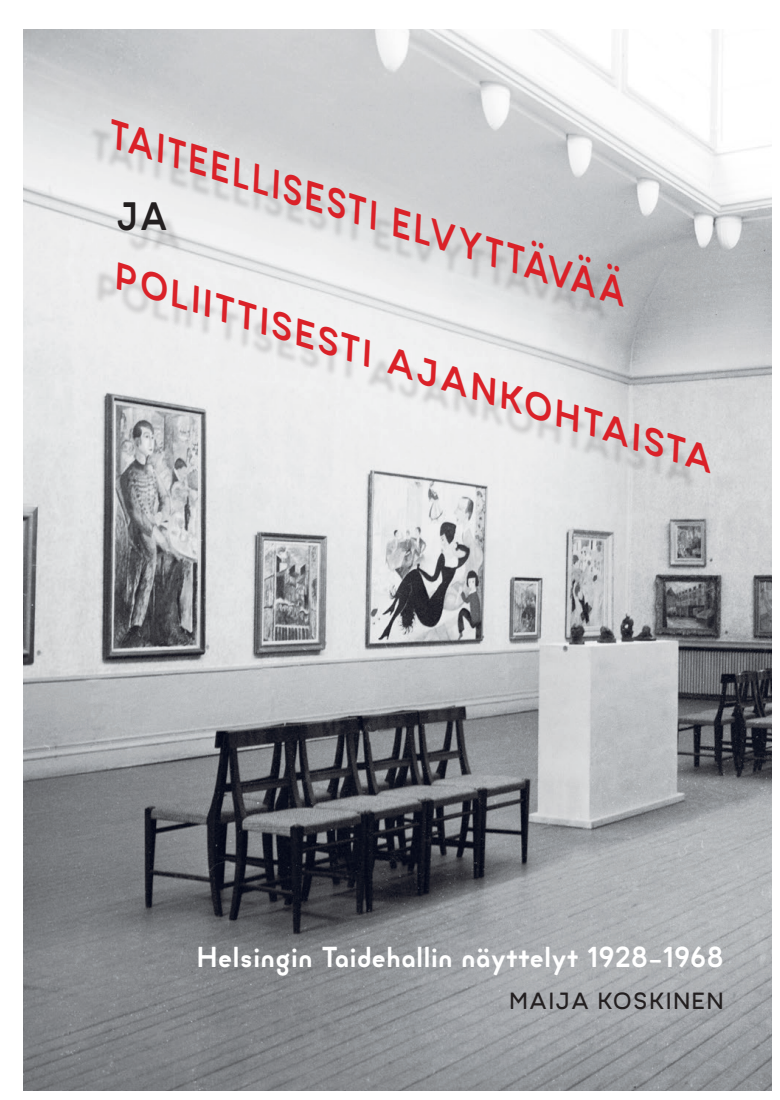

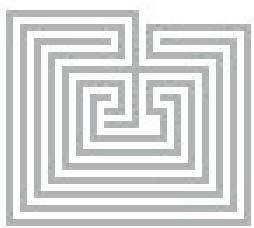


käännekohtia ja muutoksia, joiden kautta Koskinen kerii auki Taidehallin toimintaa ja tehtävää.

Koskisen tutkimus ei kuitenkaan ole pelkästään yksityiskohtainen instituutiohistoriikki. Tutkimus keskittyy Taidehallin näyttelytoimintaan ja näyttelyihin vallankäytön välineenä. Vallankäytön analyysi pilkkoutuu tutkimuksessa sekä taidekentän sisäisen vallankäytön analyysiksi - jonka keskiössä on Taidehallin ja muiden taidekentän näyttelyitä järjestävien toimijoiden kamppailu taidekäsityksistä ja asemista ja määrittelyvallasta kentällä - sekä taidekentän ulkopuolisen valtiollispoliittisen vallan läsnäolon ja vaikutusten analyysiksi. Etenkin jälkimmäinen tuottaa suomalaiseen taidehistorian tutkimukseen tervetullutta uutta tietoa kotimaisen taidekentän näyttelytoiminnan ideologisista ja poliittisista kytköksistä.

Koska Koskisen tutkimus kohdistuu ennen kaikkea Taidehallin näyttelyihin, niihin liittyvät laajat ja monipuoliset arkistolähteet toimivat tutkimuksen keskeisenä aineistona. Tämän aineiston etsiminen, läpikäyminen ja systemaattinen analyysi ovat tutkimuksen ehdottomia vahvuuksia. Koskinen on ottanut tehtäväkseen Taidehallin näyttelyprofiilin tarkastelun kaikkien siellä Hintzen toimikautena järjestettyjen näyttelyjen kautta. Tehtävä on massiivinen, sillä Taidehallissa järjestettiin kyseisinä vuosikymmeninä yli 600 näyttelyä. Koskinen onnistuu hahmottamaan näyttelyistä kuitenkin monipolvisen luokittelun ja summaamaan Taidehallin näyttelytoimintaa kokonaisuutena. Koskisen tutkimuksen voi helposti tunnistaa myös perustutkimukseksi, sillä sen näyttelyitä käsittelevät luvut - mukaan lukien niiden runsaat alaviitteet - sisältävät yksityiskohtaista tietoa Taidehallin toiminnoista ja sen keskeisistä toimijoista. Runsas ja huolellisesti valittu kuvitus elävöittää näyttelytoiminnan analyysia. Läpikäydyt näyttelyt on lisäksi ryhmitelty mittavaan ja informatiiviseen liitteeseen.

\section{Kaksi näkökulmaa valtakamppailuun}

Tutkimuksen aluksi Koskinen selvittää Taidehallin kiinnittymistä mannermaiseen Kunsthalle-traditioon ja tradition soveltamista Suomen oloihin. Traditio liittyy vaurastuvan porvariston asemaan 1800-luvun Euroopassa sekä eurooppalaiseen taideyhdistysliikkeeseen, jonka avulla voitiin rakentaa porvariston kulttuuri-identiteettiä. Koskinen osoittaa, miten etenkin saksankielisiltä alueilta periytynyt taideinstituutiomalli osoittautui hyvin soveltuvaksi myös pohjoismaisiin oloihin: malli sai suomalaisen sovelluksensa vuonna 1928 valmistuneessa Taidehallissa.

Taidekentän sisäistä vallankäyttöä Koskinen tarkastelee pureutumalla niin sanotun kansallisen taiteen - kansakunnan henkistä yhtenäisyyttä ja identiteettiä rakentamaan pyrkivän taiteen - ja kansainvälisen modernismin välisiin hankauksiin. Taidehallin näyttelyprofiilin analyysin pohjalta Koskinen on valinnut tarkempaan tapaustutkimukseen neljä näyttelyä tai näyt- telysarjaa. Hän on nimennyt ne repeämänäyttelyiksi, sillä niiden kautta konkretisoituu Koskisen mukaan Taidehallin ja muiden näyttelyjärjestäjien kamppailu taidekäsityksistä, asemista ja määrittelyvallasta taidekentällä. Nämä näyttelyt ovat Taidehallin avajaisnäyttely, vuonna 1934 järjestetty modernisminäyttelyiden sarja, Nuorten näyttely -kokonaisuus sekä Pariisin nykytaidetta -näyttely vuodelta 1952. Repeämänäyttelyt olivat tyypillisesti hengeltään modernistisia tai avantgardistisia ja esittelivät uusia taiteellisia ilmaisumuotoja ja tapoja suomalaiselle taideyleisölle. Näyttelyistä kirjoitettiin runsaasti taidekritiikkiä - jota Koskinenkin hyödyntää tapaustutkimuksissaan - ja niitä on käsitelty usein myös taidehistorian tutkimuksissa.

Taidehallin näyttelyiden systemaattinen läpikäyminen on ehdottomasti Koskisen tutkimuksen vahvin ansio, jonka avulla hän on onnistunut tuomaan Taidehallin näyttelytoiminnasta esiin piirteitä, jotka aiemmin ovat jääneet taidehistorian tutkimuksen ulkopuolelle tai unohduksiin. Nämä piirteet liittyvät Koskisen vallankäytön analyysin toiseen kulmakiveen: valtiollispoliittiseksi kutsumiinsa näyttelyihin. Taidehalli toimi 1930-60-luvuilla lukuisten ulkopoliittiseen valtapeliin kytkeytyvien näyttelyiden esittelypaikkana. Näiden näyttelyiden kautta sekä natsi-Saksa että Neuvostoliitto kävivät enemmän tai vähemmän suorasukaista poliittisideologista kamppailua näkyvyydestä ja totuuksista. Näyttelyiden kautta käytäviin 
kamppailuihin osallistui kylmän sodan aikana myös Yhdysvallat. Kyseiset näyttelyt eivät olleet vain toissijaisten poliittisten toimijoiden pelikenttä, vaan usein maan ylimpään valtiojohtoon asti ulottuvaa toimintaa. Koskinen tuo esiin, miten monet - myöhemmin kiusallisinakin näyttäytyneet - poliittisideologiset näyttelyt eivät ole jääneet vain taidehistorian tutkimuksen unohtamiksi, vaan ne on voitu jopa häivyttää kokonaan myös Taidehallin omista arkistomateriaaleista.

Valtiollispoliittiset näyttelyt tuovat kiinnostavasti esiin uudenlaisen kuvan Taidehallista ja sen näyttelyprofiilista - etenkin kun Taidehallia on totuttu pitämään kotimaista taidekenttää modernismille avanneena ja sitä taiteellisesti elvyttäneenä, mihin Koskisen väitöskirjan otsikkokin viittaa. Tutkimus osoittaa, miten Taidehalli ei suinkaan ole ollut politiikan kentän ulkopuolinen taiteen autonominen kehto - päinvastoin. Valtiovalta puuttui Taidehallin näyttelyiden kautta taidekentän toimintaan ja taiteen määrittelyihin poliittisten toimijoiden intressien ja tarpeiden mukaisesti.

\section{Avauksia jatkotutkimukselle}

Näyttelyiden analyysin jälkeen Koskinen summaa lyhyesti Bertel Hintzen persoonaa, taidekäsitystä, sosiaalisia suhteita ja poliittisia sympatioita. Kyseinen luku jää hieman irralliseksi näyttelyiden analyyseista, mutta toisaalta se kontekstualisoi koko tutkimuksen lähtökohtana toimivan Taidehallin näyttelytoiminnan prii- musmoottorin maailmankuvaa ja toimintaa. Koskinen nostaa tässä yhteydessä esiin myös Bertel Hintzen vaimon Lilli Hintzen, joka mitä ilmeisimmin toimi - miehensä kautta - keskeisessä roolissa taidekentän ytimessä. Koskinen ei analysoi tarkemmin sukupuoleen liittyvää valtaa, mutta ottaa esiin, miten Taidehalli oli täysin miesten hallussa tutkittavina vuosikymmeninä. Lilli Hintze oli kuitenkin aktiivinen taiteen sosiaalisissa verkostoissa ja vaikutti miehensä toimintaan ja näkemyksiin taiteesta. Lilli Hintze ja muut taidekentän hiljaiset ja taustalle jääneet naistoimijat ansaitsisivat oman jatkotutkimuksensa.

Koskisen tutkimuksen kohteena on nimenomaan suomalainen taidekenttä ja Taidehalli sen valtakunnallisena toimijana. Paikoin tutkimuksessa viitataan myös pääkaupungin taidekenttään. Vaikka Koskinen käy läpi valtakunnallisten ja alueellisten taiteilijaseurojen ja -ryhmien toimintaa sekä Taidehallin roolia erilaisten taidekentän toimijoiden esilletulon areenana, analyysi taidekentän keskusta-periferia-suhteista jää ohueksi. Koskinen sisällyttää analyysiinsa Taidehallin ja Ateneumin toiminnan vertailua, mutta muualla Suomessa toimineet taidemuseot ja näyttelyjen järjestäjät on rajattu tutkimuksen ulkopuolelle. Keskittyminen vain Taidehalliin tuottaa tutkimukseen pistemäisen näkökulman suomalaisen taidekentän toimintaan. Lukijalle herää kysymys, onko tutkimuksessa lopulta kyse pääkaupungin taidekentän analyysista ja mikä on pää- kaupungin ja suomalaisen taidekentän suhde. Ovatko ne sama asia? Koskinen tuo kyllä esiin, miten myös pääkaupungin ulkopuoliset ryhmät järjestivät näyttelyitä Taidehallissa ja miten pääkaupungin ulkopuoliset toimijat olivat tyytymättömiä Taidehallin pääkaupunkikeskeiseksi koettuun toimintaan. Taidehallin merkityksen analyysi alueellisen valtakamppailun areenana ja kamppailun vaikutukset taidekentän dynamiikkaan pääkaupunkiseudun ulkopuolella jäävät kuitenkin jatkotutkimuksen tehtäviksi.

Koskisen tutkimus on teoreettisten avausten osalta niukka. Tutkimukseen valittu vallan näkökulma ja Bourdieun kulttuurisosiologiasta ammentava lähestymistapa sopivat toki luontevasti tutkimusasetelmaan, mutta valinnat eivät tuota juurikaan mitään teoreettisesti uutta taidehistorian tutkimukseen. Analyysit eivät hyödynnä syvällisemmin Bourdieun teorioihin kiinteästi liittyvää maun käsitettä tai teorioita kielen osuudesta valtakamppailussa. Bourdieu voidaan perustellusti nostaa tieteen klassikoksi, ja kulttuuriin liittyvissä vallankäytön analyyseissa hänen teorioitaan onkin käytetty taajaan niin kotimaisessa kuin ulkomaisessa tutkimuksessa. Koskinen kirjoittaa hyödyntävänsä tutkimuksessaan Grenfellin ja Hardyn taideinstituutioanalyysimallia, joka tukeutuu Bourdieun teorioihin. ${ }^{5}$ Kuvailtu malli vaikuttaa sopivan hyvin aineistoon, mutta itse analyysissa mallin soveltamista on vaikea seurata, sillä siihen ei johdantoluvun jälkeen juuri palata 
Koskisen tutkimus - kuten taidehistorian tutkimus usein tekee - osallistuu sekä kohteensa merkitysten ja erityisyyden tutkimiseen että samalla niiden tuottamiseen taidehistorian diskurssissa. Tutkimuksen myötä Taidehallista piirtyy kuva suomalaisen taidekentän johtotähtenä Hintzen toimikaudella. Samalla vahvistuu jo Erik Kruskopfin luoma kuva Hintzestä yhtenä sen vaikutusvaltaisimmista portinvartijoista. ${ }^{6}$ Koskisen tutkimuksen myötä kuva Taidehallista laajenee taiteen keskeisestä areenasta valtiollisen politiikan näyttämöksi. Aiempi kuva tarkentuu sekä Taidehallin näyttelytoiminnan että Hintzen intressien ja suhdeverkoston poliittisella ja ideologisella ulottuvuudella.

\section{Viitteet}

1 Marja-Liisa Rönkkö, Suomalainen taidemuseo.

Louvren ja Louisianan perilliset. Dimensio 2 (Helsinki: Valtion taidemuseo, 1999).

2 Susanna Pettersson, Suomen Taideyhdistyksestä Ateneumiin. Fredrik Cygnaeus, Carl Gustaf Estlander ja taidekokoelman roolit. Dimensio 6 (Helsinki: Valtion taidemuseo, 2008).

3 Hanne Selkokari, Kalleuksia isänmaalle: Eliel Aspelin-Haapkylä taiteen keräilijänä ja taidehistorioitsijana (Helsinki: Suomen muinaismuistoyhdistys, 2008).

4 Esimerkiksi Anna-Kaisa Rastenberger, Tietoa, valtaa ja toimintaa - Suomalaisen valokuvataiteen kansainvälistyminen - Käsitteiden kautta järjestyvä valokuvataiteen kenttä 1990-2000-Iuvuilla (Taidehistorian väitöskirja, Helsingin yliopisto, 2015). Saatavilla: https://helda.helsinki.fi/handle/10138/153391

5 Michael Grenfell ja Cheryl Hardy, Art Rules. Pierre

Bourdieu and the Visual Arts (Berg: Oxford, 2007).

6 Erik Kruskopf, Taiteen maailmanmies Bertel Hintze 1901-1969 (Helsinki: Valtion taidemuseo, 1998).
FT, YTT, dos. Tuuli Lähdesmäki työskentelee akatemiatutkijana Musiikin, taiteen ja kulttuurin tutkimuksen laitoksella Jyväskylän yliopistossa. Lähdesmäki johtaa Euroopan tiedeneuvoston rahoittamaa Euroopan unionin kulttuuriperintöpolitiikkaa käsittelevää EUROHERIT-tutkimushanketta sekå työskentelee Cambridgen yliopiston johtamassa kulttuurista lukutaitoa tarkastelevassa Euroopan komission rahoittamassa DIALLS-tutkimushankkeessa. Hän on myös yksi Jyväskylän yliopiston Kriisit uudelleenmääriteltynä -profilointihankkeen (CRISES) johtajista.

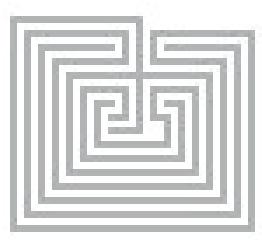

